\title{
KEANEKARAGAMAN JENIS DAN KEPADATAN KARANG LUNAK DI PERAIRAN LALANU KECAMATAN SOROPIA KABUPATEN KONAWE
}

\section{Species Diversity And Distribution Of Soft Coral in The Lalanu Waters District Of Soropia Konawe Regency}

\author{
Muhammad Fadly ${ }^{1}$, Baru Sadarun ${ }^{2}$, dan Rahmadani ${ }^{3}$ \\ ${ }^{1}$ Mahasiswa Jurusan Ilmu Kelautan, \\ Fakultas Perikanan dan Ilmu Kelautan, Universitas Halu Oleo. \\ Jl. H.E.A Mokodompit Kampus Hijau Bumi Tridharma Anduonohu Kendari 93232, Telp/Fax: (0401) 3193782 \\ ${ }^{2}$ Surel: bsadarun@gmail.com \\ ${ }^{3}$ Surel: rahmamustafa47@gmail.com
}

\begin{abstract}
Abstrak
Tujuan dari penelitian ini yaitu untuk mengetahui kondisi keanekaragaman jenis dan kepadatan karang lunak di Perairan Lalanu. Penelitian ini dilakukan melalui dua tahapan yakni pengambilan data lapangan dan analisis sampel. Pengambilan data lapangan yang dilaksanakan pada September 2018, bertempat di Perairan Lalanu, Kecamatan Soropia, Kabupaten Konawe, Provinsi Sulawesi Tenggara. Pengamatan keanekargaman dan kepadatan karang lunak menggunakan Metode Belt Transek pada tiap titik stasiun pengamatan. Lebar diameter Belt Transek yang digunakan yaitu $5 \mathrm{~m}$ dengan ukuran 2,5 m ke kanan dan 2,5 m ke kiri dengan panjang $70 \mathrm{~m}$ yang dibentangkan sejajar garis pantai dengan menggunakan meteran roll. Pada tiap stasiun dilakukan pengulangan sebanyak dua kali pengulangan. Berdasarkan hasil pengambilan data jenis karang lunak di perairan Lalanu yang ditemukan yaitu sebanyak 6 jenis yakni Sinularia, Asterospicularia $S p$, Sarcophyton Sp, Xenia, Cavernularia, dan Cespitularia. Keanekaragaman tertinggi perairan Lalanu yakni pada stasiun III dimana pada stasiun tersebut didapatkan nilai kepadatan karang lunak sebesar 0,034 ind $/ \mathrm{m}^{2}$, sedangkan Kepadatan karang lunak terendah pada stasiun I dengan jumlah $0,021 \mathrm{koloni} / \mathrm{m}^{2}$. Frekuensi kemunculan karang lunak yang ditemukan pada tiap stasiun menunjukkan bahwa dari 6 koloni karang lunak yang di temukan pada setiap stasiun, ada 2 jenis karang lunak yang memiliki frenkuensi kemunculan tertinggi (100\%) yaitu jenis Asterospicularia Sp. dan Sarcophyton Sp.
\end{abstract}

Kata kunci : Keanekaragaman, Kepadatan, Karang Lunak, Perairan Lalanu

\begin{abstract}
Purpose of this study is to determine the condition of species diversity and density of soft corals in Lalanu waters. This research was conducted through two stages, namely field data collection and sample analysis. Field data collection was carried out in September 2018, located in Lalanu Waters, Soropia District, Konawe Regency, Southeast Sulawesi Province. Observation of the diversity and density of soft corals using the Method Belt Transect at each point of the observation station. The width of thediameter Belt Transect used is $5 \mathrm{~m}$ in size $2.5 \mathrm{~m}$ to the right and $2.5 \mathrm{~m}$ to the left with a length of $70 \mathrm{~m}$ stretched parallel to the coastline using a roll meter. At each station repetitions were repeated twice. Based on the results of data retrieval of soft coral species in the Lalanu waters found as many as 6 types, namely Sinularia, Asterospicularia Sp, Sarcophyton Sp, Xenia, Cavernularia, and Cespitularia. The highest diversity of aquatic Lalanu namely at the station in the station III where the density values obtained by soft corals $0,034 \mathrm{ind} / \mathrm{m}^{2}$, whereas the lowest density of soft coral at the first station with a number of 0,021 colonies $/ \mathrm{m}^{2}$. The frequency of occurrence of soft corals found at each station showed that of the 6 soft coral colonies found at each station, there were 2 types of soft corals which had the highest occurrence of frenicity (100\%), namely the type Asterospicularia Sp. and Sarcophyton Sp.
\end{abstract}

Keywords: Diversity, Density, Soft Coral, Lalanu Water

\section{Pendahuluan}

Ekosistem terumbu karang mempunyai fungsi ekologis yaitu sebagai habitat untuk berkembang biak, pengasuhan, mencari makan dan berlindung bagi biota lain. Biota laut yang hidup di ekosistem ini yaitu vertebrata seperti ikan, reptil dan mamalia, maupun avertebrata seperti mollusca, echinodermata, crustacea, vermes/cacing. Terumbu karang juga mempunyai fungsi melindungi pantai dari hempasan ombak dan arus laut. Selain itu keindahan alam laut dan terumbu karang sendiri dapat meningkatkan taraf hidup masyarakat sebagai daerah pariwisata bahari (Nybakken, 1992).

Karang lunak merupakan bagian dari ekosistem terumbu karang yang dianggap penting dan merupakan komponen kedua terbesar sesudah karang batu serta mempunyai peranan yang penting dalam ekologi terunbu karang, seperti memberikan kontribusi pada pembentukan terumbu (Manuputty, 2002). 
Keberadaan karang lunak saat ini menjadi perhatian besar bagi para peneliti karena terdapat kandungan senyawa aktif. Ekstrak metabolit dari spons dipercaya mengandung senyawa bioaktif yang mempunyai sifat sitotoksin, anti tumor, anti virus, anti inflamasi, anti fungi dan lainnya. Selain sebagai sumber senyawa bahan alam, karang lunak juga memiliki manfaat yang lain, yakni digunakan sebagai indikator biologi untuk pemantauan pencemaran laut, indikator dalam interaksi komunitas, dan sebagai hewan bernilai ekonomis untuk hiasan akuarium laut.

Keanekaragaman jenis karang lunak pada suatu habitat umumnya ditentukan oleh kondisi perairan yang jernih dan tidak memiliki arus kuat. Sebaran karang lunak dapat ditemui pada setiap kondisi kedalaman yang berbeda dengan tingkat kecerahan yang cukup untuk pertumbuhannya. Salah satunya yaitu pada Perairan Lalanu.

Perairan Lalanu merupakan salah satu desa yang terdapat di Kecamatan Soropia, Kabupaten Konawe, Provinsi Sulawesi Tenggara. Perairan Lalanu memiliki potensi sumber daya alam laut terutama karang lunak yang sangat potensial untuk dikembangkan, akan tetapi habitat hidup karang lunak pada pulau ini terlihat terus mengalami degradasi sehingga dikhawatirkan mengancam kelestarian biota laut di dalamnya. Berbagai macam sumber kerusakan baik karena alam maupun antropogenik dapat mengancam kelestarian karang lunak. Akan tetapi kerusakan terbesar adalah karena ulah manusia. Dari pernyataan tersebut maka perlu dilakukan penelitian untuk mengetahui lebih jelas pada kondisi keanekaragaman jenis dan sebaran karang lunak di Perairan Lalanu.

\section{Bahan dan Metode}

Penelitian ini dilakukan melalui dua tahapan yakni pengambilan data lapangan dan analisis data. Pengambilan data lapangan yang akan dilaksanakan pada September 2018, bertempat di Perairan Lalanu, Kecamatan Soropia, Kabupaten Konawe, Provinsi Sulawesi Tenggara.

Langkah awal sebelum melakukan penelitian yaitu survey pendahuluan Survey ini bertujuan untuk melihat kondisi awal lokasi penelitian. Hasil dari survey ini dijadikan sebagai dasar untuk penentuan titik pengambilan data (stasiun penelitian).

Penentuan titik stasiun penelitian menggunakan metode purposive sampling yaitu didasarkan pada keberadaan karang lunak. Pada tahap ini sekaligus melakukan penandaan stasiun penelitian dengan menggunakan GPS. Titik stasiun penelitian, yaitu sebagai berikut: Stasiun I, stasiun ini berada pada Perairan Lalanu dengan titik koordinat $\quad 3^{\circ} 53^{\prime} 18.63 " \mathrm{LS}$ dan $122^{\circ} 36^{\prime} 41.33 " B T$. Stasiun ini mengarah ke arah laut lepas dan meripakan daerah pengeboman ikan. Stasiun II, Stasiun ini berada pada Perairan Lalanu dengan titik koordinat $\quad 3^{\circ} 53^{\prime} 18.12^{\prime \prime} \mathrm{LS}$ dan $122^{\circ} 36^{\prime} 56.90 " B T$. Stasiun ini mengarah ke laut lepas. Stasiun III, Stasiun ini berada pada Perairan Lalanu dengan titik koordinat $3^{\circ} 53^{\prime} 26.45^{\prime \prime} L S$ dan $122^{\circ} 37^{\prime} 0.95 " B T$. Stasiun ini letaknya dekat dengan vegetasi mangrove dan dekat dengan muara.

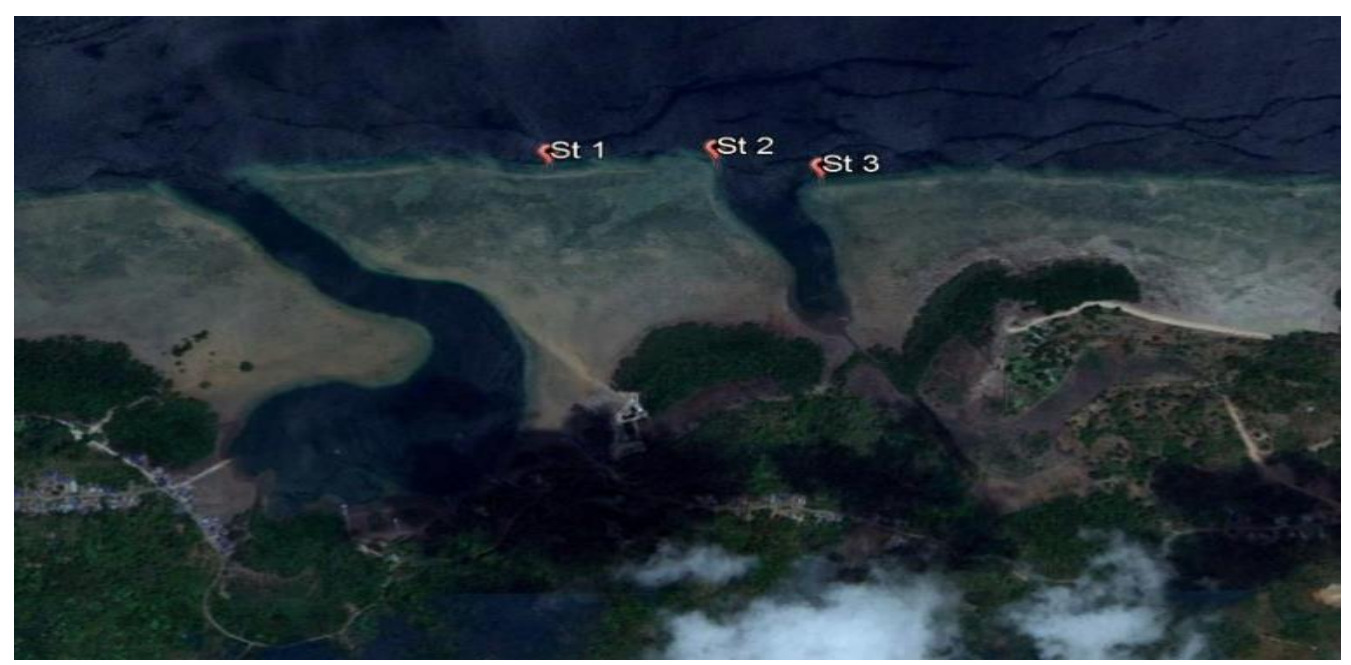

Gambar 1. Lokasi penelitian(Sumber : Google.com, 2018) 




Gambar 2. Skema Belt Transect

Adapun metode pengambilan data yang akan dilaksanakan yakni pengambilan data keanekaragaman karang lunak menggunakan Metode Belt Transek serta pengelolahan datanya menggunakan microsof excel.

Pengamatan kepadatan karang lunak menggunakan Metode Transek Belt pada tiap titik stasiun pengamatan. Lebar diameter transek belt yang digunakan yaitu 5 meter dengan ukuran 2,5 me ke kanan dan 2,5 m ke kiri dengan panjang $70 \mathrm{~m}$ yang dibentangkan sejajar garis pantai dengan menggunakan meteran roll. Pada tiap stasiun dilakukan pengulangan sebanyak dua kali pengulangan. Hal ini dikarenakan untuk mendapatkan data luasan tiap stasiun serta data keanekaragaman dan sebaran karang lunak.

Identifikasi karang lunak dilakukan dengan mengambil foto karang lunak yang terdapat di dalam Transek Belt pada tiap stasiun dilakukan pengulangan sebanyak dua kali pengulangan, kemudian dibantu menggunakan buku identifikasi berdasarkan Colin dan Aneson (1995).

Parameter fisik kimia perairan berupa suhu, salinitas, kecerahan, kedalaman, kecepatan arus dan intensitas cahaya. Pengukuran parameter fisik kimia perairan dilakukan pada tiap-tiap stasiun penelitian yang selanjutnya dijelaskan sebagai berikut:

Pengukuran suhu menggunakan thermometer yaitu dengan cara mencelupkan thermometer ke permukaan perairan dan sedapat mungkin saat pengukuran thermometer tidak disentuh oleh tangan. Nilai suhu dapat dilihat pada skala yang ditunjukan oleh thermometer. Pengukuran suhu tidak hanya dilakukan di permukaan air, namun juga di tiap kedalaman yang berbeda pada zona terumbu karang tempat sampel karang lunak yang diambil.

Salinitas diukur dengan mengunakan handrefractometer yaitu terlebih dahulu dilakukan kalibrasi pada alat tersebut dengan cara membilas kaca prisma menggunakan air tawar kemudian dikeringkan dengan tissu. Setelah itu sampel air laut diteteskan pada kaca prisma kemudian ditutup, selanjutnya handrefractometer diarahkan ke cahaya, untuk melihat nilai salinitas yang terbaca pada alat.

Kecepatan arus (V) diukur dengan mengunakan layangan arus yaitu dengan cara dihayutkan di atas permukaan air hingga tali pada alat tersebut menempuh jarak (s) tertentu, kemudian dicatat waktu (t) tempuh alat tersebut saat mulai dihanyutkan hingga membentang lurus dengan mengunakan stopwatch dan dihitung menggunakan persamaan (1) :

$\mathrm{V}=\frac{\mathrm{s}}{t}$

Dimana $: \mathrm{V}=$ Kecepatan arus $(\mathrm{m} / \mathrm{s}) ; \mathrm{s}=$ Jarak tempuh layangan arus $(\mathrm{m}) ; \mathrm{t}=$ Waktu tempuh layangan arus (s).

1. Kecerahan Perairan

Alat yang digunakan dalam penentuan kecerahan perairan adalah secchi disk. Alat secchi disk ini dicelupkan perlahanlahan ke dalam air kemudian diamati saat secchi disk mulai tidak terlihat warna hitam dan putih dan diukur kedalamannya (m). Secchi disk diangkat lagi secara perlahanlahan dan diamati saat secchi disk mulai terlihat warna hitam dan putih lagi dan diukur kedalaman $(\mathrm{m})$ dan diukur pula kedalaman perairan (Z), setelah didapat kedua nilai kedalaman tersebut, kecerahan (C) diukur dengan persamaan 
$C=0,5 \frac{(m+n)}{Z} \times 100 \%$

Keterangan:

$\mathrm{C}=$ Kecerahan

$\mathrm{m}=$ Kedalaman (tidak terlihat di secchi disk )

$\mathrm{n}=$ Kedalaman (mulai terlihat di secchi disk)

$\mathrm{z}=$ Kedalaman perairan

\section{Analisis Data}

Keanekaragaman karang lunak pada Perairan Lalanu dianalisis secara deskriptif berdasarkan total jumlah karang lunak yang ditemukan. Tingkat keanekaragaman karang lunak yang ada dalam stasiun pengamatan (Benahayu, 2004).

Kepadatan individu spons didefenisikan sebagai jumlah individu dibagi luas daerah pengamatan di setiap stasiun. Kepadatan dihitung dengan menggunakan rumus Brower dan Zar (1990) pada persamaan (4) yaitu :

$N=\frac{n}{A}$

Dimana :

$N=$ Kepadatan Individu (ind $/ \mathrm{m}^{2}$ )

$n$ = Jumlah individu yang diperoleh tiap stasiun

$A=$ Luas daerah pengamatan $\left(\mathrm{m}^{2}\right)$

Frekuensi kemunculan berdasarkan jumlah kemunculan setiap jenis karang lunak pada setiap stasiun pengamatan digunakan rumus sebagai berikut, (Odum,1993) yaitu :

$\mathrm{F}=\frac{\sum \mathrm{M}}{\sum \mathrm{St}} \times 100 \%$

Dimana:

F = Frekuensi Kemunculan Setiap Jenis

Spons

$\sum \mathrm{M}=$ Jumlah Kemunculan jenis ke-i pada

Setiap Stasiun

$\sum \mathrm{St}=$ Jumlah Stasiun

\section{Hasil dan Pembahasan}

Berdasarkan hasil pengambilan data jenis karang lunak di perairan Lalanu yang ditemukan yaitu sebanyak 6 jenis yakni Sinularia, Asterospicularia, Sarcophyton, Xenia, Cavernularia, dan Cespitularia. Sebagian besar dari jenis - jenis karang lunak berbeda dari yang ditemukan di Perairan Waworaha oleh Wanda (2018) yang ditemukan sebanyak 8 jenis karang lunak.

Karang lunak yang ditemukan di perairan Lalanu pada umumnya kebanyakan menyukai perairan yang masih dalam kondisi dengan intensitas cahaya yang tinggi, hal tersebut sesuai dengan nilai kecerahan yang didapat pada lokasi penelitian yakni pada stasiun III memiliki nilai kecerahan tertinggi $3,7 \mathrm{~m}$. Tambrin (2006) menyatakan bahwa kecerahan dan cahaya merupakan faktor yang dapat mempengaruhi bagi kehidupan karang laut. Maka daripada itu stasiun III memiliki keanekaragaman karang lunak yang tinggi yaitu sebanyak 5 jenis dengan 24 koloni.

Stasiun I memiliki keanekaragaman karang lunak yang paling terendah yaitu sebanyak 3 jenis dengan jumlah 15 koloni. Hal ini dikarenakan lokasi ini banyak patahan karang (rubble) sehingga mempengaruhi kondisi parameter perairan pada stasiun I seperti halnya kecerahan.

Keanekaragaman karang lunak yang ditemukan dari ke 3 stasiun tidaklah merata, hal tersebut merupakan kelebihan dari karang lunak yang menunjukkan keanekaragaman yang berbeda pada tiaptiap daerah. Menurut Cool dan Sammarco, (1986), hal tersebut dikarenakan reproduk aseksual yang banyak dilakukan oleh jenis karang lunak menyebabkan terbentuknya suatu koloni dan perkembangannya yang mengelompok. Hubungan persaingan dengan organisme terumbu yang lain jelas bepengaruh dan penting dalam menentukan penyebaran dari karang lunak.

Keanekaragaman tertinggi perairan Lalanu yakni pada stasiun III dimana pada stasiun tersebut didapatkan nilai kepadatan karang lunak sebesar $0.034 \mathrm{ind} / \mathrm{m}^{2}$ dimana jenis koloni karang lunak Asterospicularia Sp., dan Xenia Sp., dengan nilai 0.009 $\mathrm{ind} / \mathrm{m}^{2}$ (Tabel 4). Hal tersebut sesuai dengan nilai parameter lingkungan perairan Fisika dan Kimia yang didapatkan untuk mendukung pertumbuhan dari karang lunak seperti halnya suhu, kecerahan, kecepatan arus, dan salinitas.

Kondisi kecerahan pada stasiun III diperoleh nilai sebesar $3,7 \mathrm{~m}$ kondisi tersebut masih dalam kondisi normal bagi organisme laut salah satunya adalah karang lunak. Hal tersebut sesuai pernyataan Manuputty (2008). Cahaya yang masuk ke perairan dapat menembus dengan sempurna hingga kedasar perairan. Batas kedalaman untuk pertumbuhan karang lunak sejalan dengan bertambahnya tingkat kecerahan suatu perairan. 
Tabel 1. Parameter Fisika Kimia Perairan Lalanu

\begin{tabular}{llccc}
\hline \multirow{2}{*}{ No } & Parameter Perairan & \multicolumn{3}{c}{ Stasiun } \\
\cline { 3 - 5 } & Fisika & ST I & ST II & ST III \\
\hline \multirow{2}{*}{1} & Suhu $\left({ }^{\circ} \mathrm{C}\right)$ & 28 & 30 & \\
2 & Kecerahan (m) & 3,6 & 3,6 & 30 \\
3 & Kecepatan arus (m/s) & 0.05 & 0.08 & 0.06 \\
& Kimia & & & \\
4 & Salinitas (ppt) & 35 & 35 & 34,5 \\
\hline
\end{tabular}

Tabel 2. Jenis Karang Lunak pada perairan Lalanu

\begin{tabular}{clccc}
\hline \multirow{2}{*}{ No } & \multirow{2}{*}{ Jenis Koloni Karang Lunak } & \multicolumn{3}{c}{ Jumlah Koloni Karang Lunak } \\
\cline { 3 - 5 } & & ST I & ST II & ST III \\
\hline 1 & Sinularia Sp. & 5 & 5 & \\
2 & Asterospicularia Sp. & 6 & 4 & 6 \\
3 & Sarcophyton Sp. & 4 & 2 & 4 \\
4 & Xenia Sp. & & 3 & 6 \\
5 & Cavernularia Sp. & & 3 & 4 \\
6 & Cespitularia Sp. & 15 & 17 & 4 \\
\hline & Jumlah & & & 24 \\
\hline
\end{tabular}

Tabel 3.Kepadatan Karang Lunak pada Perairan Lalanu

\begin{tabular}{clccc}
\hline \multirow{2}{*}{ No } & \multirow{2}{*}{ Jenis Koloni Karang Lunak } & \multicolumn{3}{c}{ Jumlah Koloni Karang Lunak (ind $\left./ \mathbf{m}^{\mathbf{2}}\right)$} \\
\cline { 3 - 5 } & & ST I & ST II & ST III \\
\hline 1 & Sinularia Sp. & 0.007 & 0.007 & \\
2 & Asterospicularia Sp. & 0.009 & 0.006 & 0.009 \\
3 & Sarcophyton Sp. & 0.006 & 0.003 & 0.006 \\
4 & Xenia Sp. & & 0.004 & 0.009 \\
5 & Cavernularia Sp. & & & 0.006 \\
6 & Cespitularia Sp. & 0.021 & 0.004 & 0.006 \\
\hline & Total & & & 0.034 \\
\hline
\end{tabular}

Tabel 4. Frekuensi Kemunculan Karang Lunak

\begin{tabular}{|c|c|c|c|c|c|c|c|}
\hline \multirow{2}{*}{ No } & \multirow{2}{*}{$\begin{array}{c}\text { Jenis Koloni Karang } \\
\text { Lunak }\end{array}$} & \multicolumn{3}{|c|}{ Stasiun } & \multirow{2}{*}{$\sum \mathbf{M}$} & \multirow{2}{*}{$\sum \mathbf{S t}$} & \multirow{2}{*}{$\mathbf{F}(\%)=\left(\sum M / \sum S t\right) * 100$} \\
\hline & & I & II & II & & & \\
\hline 1 & Sinularia $\mathrm{Sp}$. & $(+)$ & $(+)$ & $(-)$ & 2 & 3 & 66.67 \\
\hline 2 & Asterospicularia $\mathrm{Sp}$. & $(+)$ & $(+)$ & $(+)$ & 3 & 3 & 100 \\
\hline 3 & Sarcophyton Sp. & $(+)$ & $(+)$ & $(+)$ & 3 & 3 & 100 \\
\hline 4 & Xenia Sp. & $(-)$ & $(+)$ & $(+)$ & 2 & 3 & 66.67 \\
\hline 5 & Cavernularia Sp. & $(-)$ & $(-)$ & $(+)$ & 1 & 3 & 33.33 \\
\hline \multirow[t]{2}{*}{6} & Cespitularia Sp. & $(-)$ & $(+)$ & $(+)$ & 2 & 3 & 66.67 \\
\hline & Total & 3 & 5 & 5 & 13 & 3 & 66.67 \\
\hline
\end{tabular}

Keterangan: (+) Ada; (-) Tidak ada 
Kepadatan karang lunak terendah terdapat pada stasiun I dengan jumlah 0.021 $\mathrm{ind} / \mathrm{m}^{2}$ dimana Sinularia Sp., merupakan jenis koloni karang lunak yang mendominasi kepadatan di perairan tersebut dengan nilai kepadatan $0.007 \mathrm{ind} / \mathrm{m}^{2}$, hal tersebut dikarenakan stasiun I terletak di bibir teluk yakni di daerah barrier reef yang memiliki kecepatan arus terendah dari semua stasiun. Pada stasiun I memiliki kecepatan arus yaitu $0,05 \mathrm{~m} / \mathrm{s}$, yang menyebabkan rendahnya kecepatan arus pada stasiun I merupakan daerah barrier reef sengga tidak dapat pengaruh oleh arus laut lepas. Menurut Sugianto (2004), bahwa kecepatan arus merupakan faktor yang sangat berpengaruh terhadap karang lunak untuk memperoleh sumber air yang segar, memberi oksigen, mencegah terjdinya sedimentasi, sumber nutrient dan makanan.

Jenis karang lunak yang nilai kepadatannya tertinggi yaitu koloni Asterospicularia $S p$. Dengan nilai kepadatan pada stasiun I 0,009 ind $/ \mathrm{m}^{2}$, stasiun II 0,006 ind $/ \mathrm{m}^{2}$, dan stasiun III $0,009 \mathrm{ind} / \mathrm{m}^{2}$. Karang lunak rentan terhadap terjadinya abrasi, kehilangan habitat/tempat tinggala, dan bentuk gangguan lain oleh badai gelombang dan pencampuran pergerakan dari pasir dan rubble. Hanya karang lunak yang merayap seperti Sinularia atau Cladiella, dan beberapa species lain, seperti Capnella, Paralemnalia, Asterospicularia dan Xenia yang bisa mentoleransi aksi gelombang, dan dapat ditemukan di daerah reef flat pada daerah pecahnya ombak Fabricus dan Alderslade (2001).

Frekuensi karang lunak merupakan suatu nilai dimana beberapa kalikah suatu karang lunak tersebut muncul pada suatu lokasi penelitian. Frekuensi kemunculan karang lunak yang ditemukan pada tiap stasiun di perairan Lalanu menunjukkan bahwa dari 6 jenis karang lunak yang di temukan pada setiap stasiun diantaranya Asterospicularia Sp., Sarcophyton Sp., Sinularia Sp., Xenia Sp., Cespitularia Sp, dan Cavernularia Sp., ( Tabel 5). Asterospicularia Sp., dan Sarcophyton Sp., merupakan jenis karang lunak dengan frenkuensi kemunculan yang tinggi dengan nilai $100 \%$. Jenis karang lunak Cavernularia Sp., memiliki frekuensi kemunculan yang rendah dengan nilai $33.33 \%$.
Karang lunak rentan terhadap terjadinya abrasi, kehilangan habitat/tempat tinggala, dan bentuk gangguan lain oleh badai gelombang dan pencampuran pergerakan dari pasir dan rubble. Hanya karang lunak yang merayap seperti Sinularia atau Cladiella, dan beberapa species lain, seperti Capnella, Paralemnalia, Asterospicularia dan Xenia yang bisa mentoleransi aksi gelombang, dan dapat ditemukan di daerah reef flat pada daerah pecahnya ombak Fabricus dan Alderslade (2001). Hal tersebut sesuai pendapat dari Piato (2015), bahwa frekuensi kemunculan menunjukkan besar kecilnya presentasi kehadiran suatu jenis biota. Semakin tinggi nilai kehadiran (\%) berarti semakin sering biota tersebut dijumpai pada kawasan teresebut.

\section{Simpulan.}

Berdasarkan hasil penelitian yang telah dilakukan di Perairan Lalanu dapat disimpulkan sebagai berikut:

1. Keanekaragaman karang lunak di perairan Lalanu yang di temukan pada semua stasiun penelitian yaitu sebanyak 6 spesies karang lunak yakni Sinularia Sp, Asterospicularia Sp, Sarcophyton Sp, Xenia Sp, Cavernularia Sp, dan Cespitularia Sp.

2. Kepadatan karang lunak di perairan Lalanu adalah pada stasiun III dengan nilai kepadatan 0.034 koloni $/ \mathrm{m}^{2}$, sedangkan nilai kepadatan terendah terdapat pada stasiun I demgan nilai kepadatan $0.021 \mathrm{koloni} / \mathrm{m}^{2}$.

3. Frekuensi kemunculan karang lunak di perairan Lalanu yang tertinggi yaitu pada jenis Asterospicularia Sp dan Sarcophyton Sp (100\%)

\section{Daftar Pustaka}

Anna E. W. Manuputty. 1986. Karang lunak, salah satu penyusun terumbu karang. Oseana. XI(4) : 131 - 141. ISSN 0216 $-1877$.

Bayer, F. M., M. Grasshoff, and J. Verseveldt. 1983. Illustrated Trilingual Glossary Of Morphological And Anatomical Terms Applied To Octocorallia. E. J. Brill. Leiden.

Bayer, F.M., 1956. Octocorallia. in: Treatise on Invertebrata Paleontology, 
Part $F$ Coelenterata. University of Kansas Press, Lawrence.

Brower, J.E., J.H. Zar dan C. Von Ende. 1990. General Ecology. Field and Laboratory Methods. Wm. C. Brown Company Publisher, Dubuque, Iowa.

Dahuri, R., I.N.S. Putera, Zairion dan Sulistiono, 1993. Metode dan Analisi Biota Perairan. Pusat Penelitian Lingkungan Hidup, Lembaga Penelitian IPB. Bogor.

Dean, A dan Kleine, D. 2012. Buku Kegiatan "Terumbu Karang dan Perubahan Iklim". Coral Watch. The University of Queensland.

Ellis, E dan L. Sharon, 2005. The Culture of Soft Corals (Order: Alcyonacea) for The Marine Aquarium Trade. Center for Tropical and Subtropical Aquaculture Publication. $137 \mathrm{~h}$.

Fabricius, K. dan P. Aldersade. 2001. Soft Coral And Sea Fans: A Comprehensive Guide to Tropical Shallow- Water Genera of the CentralWest Pasific, the Indian Ocean and The Red Sea. Institut of Marine Science. Twonsville.

Fossa SA, Nilsen AJ. 1998. The Modern Coral Reef Aquarium. Volume 2. Birgit Schmettkamp Verlag.

Hardiningtyas, S. D. 2009. SKRIPSI "Aktivitas Antibakteri Ekstrak Karang Lunak Sarcophyton sp. yang Difragmentasi dan Tidak Difragmentasi di Perairan Pulau Pramuka, Kepulauan Seribu". Departemen Teknologi Hasil Perairan. FPIK. IPB.

Hutagalung, et al., 1997, Metode Analisa Air Laut, Sedimen, dan Biota, Lembaga Ilmu Pengetahuan Indonesia, Jakarta.

Manuputty, A. E. W. 1996. Pengenalan beberapa Karang Lunak (Octocorallia, Alyonecea) di Lapangan. Oseana, vol. XXI. Puslitbang-Oseanologi, Lembaga Ilmu Pengetahuan Indonesia. Jakarta. 4: $1-11$

Manuputty, A. E. W. 2002. Karang Lunak (Soft Coral) Perairan Indonesia. Lembaga Ilmu Pengetahuan Indonesia. Pusat Penelitian Oseanografi.Jakarta.

Murniasih, T. 2005. "Substansi Kimia untuk Pertahanan Diri dari Hewan Laut Tak Bertulang Belakang". Oseana, Volume XXX, Nomor $2: 19$ - 27.
Nyabakken, J. W. 1992. Biologi laut Suatu Pendekatan Ekologi. Cetakan ke-2. PT Gramedia Pustaka Utama. Jakarta.

Odum, E.P. 1993. Dasar-dasar Ekologi. Terjemahan Tjahjono Samingan. Edisi Ketiga. Yogyakarta: Gadjah Mada University Press.

Patrick L. Colin and Arneson, C. 1995. Tropical Pasific Invertebrates : A Field Guide to the Marine Invertebrates Occuring on Tropical Pasific Coral Reefs, Sragrass Beds and Mangrove. Coral Reer Press. California.

Rowley SJ, Pochon X and Watling L. 2015. Environmental influences on the IndoPacific octocoral Isis hippuris Linnaeus 1758 (Alcyonacea: Isididae): genetic fixation or phenotypic plasticity. PeerJ, DOI 10.7717/peerj.1128. Department of Geology and Geophysics, University of Hawai'i at Manoa, Honolulu, HI, USA

Sadarun, B., dkk. 2008. Petunjuk Pelaksanaan Transplantasi Karang. Direktorat Konservasi dan Taman Nasional Laut. Direktorat Jenderal Kelautan, Pesisir dan Pulau-Pulau Kecil. Departemen Kelautan dan Perikanan. Jakarta. 36 hal.

Shannon, C.E. \& W. Wiever. 1963. The Mathematical Theory of Communication.University Illinois Press. Urbane. $117 \mathrm{pp}$

Supriharyono, 2000. Pengelolaan Ekosistem Terumbu Karang. Djambatan. Jakarta. 